\title{
Difficult factors in Management of Impacted Dental Prosthesis in Esophagus
}

\author{
Efiaty Arsyad Soepardi
}

\begin{abstract}
Abstrak
Gigi tiruan yang tertelan dan tersangkut di esofagus, merupakan kasus emergensi yang memerlukan intervensi esofagoskopi segera untuk mengeluarkannya. Tujuan penelitian ini untuk menilai faktor-faktor yang dapat mempersulit dalam menegakkan diagnosis dan penatalaksanaannya serta komplikasi tindakan. Penelitian retrospektif ini menganalisa rekam medik dan catatan esofagoskopi pasien dengan benda asing di esofagus yang datang ke RSCM periode antara Januari 1997 dan Desember 2003. Foto leher-dada dan esofagoskopi dilakukan pada semua pasien. Lama waktu esofagoskopi yang dipakai untuk mengeluarkan gigi tiruan dicatat dan bila waktu tercatat kurang dari 60 menit berarti tindakan esofagoskopi tidak sulit dan bila waktu tercatat 60 menit atau lebih berarti esofagoskopi sulit. Beberapa faktor penyulit dianalisa secara statistik. Ada 53 pasien tertelan gigi tiruan, tetapi hanya 51 pasien yang diteliti karena 2 kasus dieliminasi. Terdapat 22 kasus tidak sulit dan 29 kasus sulit dan 2 orang di antaranya perlu dilakukan servikotomi. Kesimpulan faktor penyulit untuk menegakkan diagnosis adalah ketidakjelasan anamnesis, gigi tiruan tidak dapat dideteksi dengan X-ray dan pada esofagoskopi tidak ditemukan. Kesulitan penatalaksanaan dipengaruhi oleh lama waktu tertelan, kegagalan pada ekstraksi pertama, ukuran akrilik dengan jumlah gigi serta adanya kawat yang berada di luar. (Med J Indones 2005; 14: 33-6)
\end{abstract}

\begin{abstract}
A dental prosthesis which ingested and impacted in esophagus, is an emergency case and life threatening, so require immediate esophagoscopy intervention for removing. The objective of this study is to assess some factors can caused dtfficulties in diagnosing and treating the ingested and impacted dental prosthesis in the esophagus and their complications. This retrospective study analyzed patient's chart whose underwent esophagoscopy for removing the impacted dental prosthesis in Dr. Cipto Mangunkusumo General Hospital, Jakarta, Indonesia during a period between January 1997 and December 2003. Neck-chest X-ray and esophagoscopy were performed in all patients to identify the existence of the dental prosthesis as a diagnostic and treatment procedure. The length of time for removing the dental prosthesis was recorded and stated as a less difficult esophagoscopy when it takes time less than 60 minutes and as a difficult esophagoscopy takes 60 minutes or longer. Some risk difficulties factors were statistically analyzed. There were 53 patients of ingested dental prosthesis in esophagus. Only 51 cases were analyzed According to the length of time for removing the dental prosthesis by esophagoscopy, 22 patients were recorded as less difficult cases and 29 patients as difficult cases. Two cases among the cases needed cervicotomy after unsuccessful esophagoscopy removal. The difficulties to diagnose an impacted dental prosthesis in the esophagus caused by unreliable clinical history, unclear signs and symptoms, unable to be detected by X-ray and was not found during esophagoscopy. The difficulties in treating due to mucosal laceration, edema, bleeding, failure of the first extraction and conformity with the size and shape, the wire outside the dental prosthesis and the length of time stayed in the esophagus. (Med J Indones 2005; 14: 33-6)
\end{abstract}

Keywords: ingested dental prosthesis, radioluscent foreign body, length of time of esophagoscopy

A dental prosthesis is a replacement of one or more tooth lost, by a plastic or porcelain tooth with acrylic base holding it in place or with metal claps to secure it to adjacent teeth. A dental prosthesis can make by a dentist or by a dental technician. The number of dental prosthesis ingested and impacted in esophagus has increased in the last few years as a result of

Department of Otorhinolaringology, Faculty of Medicine University of Indonesia/Dr. Cipto Mangunkusumo Hospital, Jakarta, Indonesia increasing improper dental prosthesis users. ${ }^{1,2,4,5}$ Dental prosthesis users should be periodically check by their dentist every 2 years to make sure it still fitting well. Usually, after using the dental prosthesis for several years, the shape of the ridges might shrink later. A dental prosthesis which impacted in esophagus is an emergency case and life threatening since it has multiple sharp and rigid edges and requires immediate management and prompt treatment. ${ }^{1-3}$ Difficulties in diagnosing and treating have been a challenge for otorhino laryngologist. The difficulties increased by unreal history, unclear signs 
and symptoms and could not be identified by plain neck \& chest X-ray and esophagoscopy. The problem in management are not available the endoscopic instruments for grasping the dental prostheses and skilled endoscopic team. Extraction of the dental prosthesis, which impacted in the esophagus was perceived to be a risky procedure with a high rate complications. ${ }^{1,4-7}$ Dental prosthesis with metal claps or retaining wires outside, predispose to imbed in esophageal wall. When unsuccessful esophagoscopy for removing, surgical removal cervicotomy or thoracotomy should be done immediately., ${ }^{3,7}$

The purpose of this study is to assess the difficult factors in diagnosing and the management the ingested dental prosthesis which impacted in esophagus and their complications.

\section{METHODS}

Data was derived from medical charts of the patients who admitted to Dr. Cipto Mangunkusumo General Hospital, Jakarta, Indonesia with the history of dental prosthesis ingestion between January 1997 and December 2003. The database information included gender, age, history, signs and symptoms, radiological evaluation, length of ingested time, length of time for esophagoscopy, location of the dental prosthesis in the esophagus, size of the acrylic and the amount of the tooth and complications during the procedure. Neckchest X-ray and esophagoscopy were performed in all patients to identify the dental prosthesis. Rigid esophagoscopy as a gold standard for diagnostic and treatment procedures were performed by endoscopic Otorhinolaryngologist team under general anesthesia by an anesthesiologist. The length of time for esophagoscopy in removing the dental prosthesis was recorded and stated as less difficult case when it takes time less than 60 minutes and difficult case when it takes 60 minutes or longer. The data were analyzed statistically.

\section{RESULTS}

There were 53 ingested dental prosthesis patients who admitted the Otorhinolaryngology Department Dr. Cipto Mangunkusumo General Hospital, Jakarta, Indonesia between January 1997 and December 2003. Thirty three patients came directly to the Emergency ward, 12 patients were consulted by other hospitals caused by unavailability the instrument for grasping the dental prosthesis and 8 patients were consulted caused by their failure in removing the dental prosthesis by esophagoscopy. One case died before repeated esophagoscopy caused by empyema thoracis. One case belong to less difficult group failed to diagnose caused by unable to be detected by X-ray and esophagoscopy, although he has real history and clear signs and symptoms. They were excluded to the criterion.

Only 51 cases were analyzed statistically. Less difficult cases 22 patients $(43,1 \%)$ and 29 patients $(56,9 \%)$ as difficult cases.

There were 41 men and 10 women and their age varied from 13 to 68 years with the mean age of 48.6 years. In male group, the history of ingested dental prosthesis while they were eating, drinking, sleeping or coughing and in female group while they were eating and drinking. Odinophagia or painful in swallowing was suffered by all of the patients. Dysphagia or difficult to swallow occurred in 25 patients and hypersalivation in 4 patients. One patient could have more than one symptom and sign. Twenty five dental prosthesis using wire as retention pin and two dentures using metal claps outside the acrylic. After esophagoscopy removal, medical characteristic of the patients were analyzed. 
Table 1. Demographic and medical characteristics of subjects ingested dental prosthesis

\begin{tabular}{|c|c|c|c|c|c|c|c|}
\hline \multirow{3}{*}{$\begin{array}{c}\text { Medical } \\
\text { Characteristic }\end{array}$} & \multicolumn{4}{|c|}{ Esophagoscopy } & \multirow{3}{*}{$\begin{array}{l}\text { Crude } \\
\text { Odd } \\
\text { ratio }\end{array}$} & \multirow{3}{*}{$\begin{array}{c}95 \% \\
\text { Confidence } \\
\text { intervals }\end{array}$} & \multirow{3}{*}{$\mathbf{P}$} \\
\hline & & $\begin{array}{l}\text { Less difficult } \\
\quad(n=22)\end{array}$ & & $\begin{array}{c}\text { Difficult } \\
(n=29)\end{array}$ & & & \\
\hline & $\mathbf{N}$ & $\%$ & $\mathbf{N}$ & $\%$ & & & \\
\hline \multicolumn{8}{|l|}{ Gender } \\
\hline Male & 18 & 43,9 & 23 & 56.1 & 1.00 & Reference & \\
\hline Female & 4 & 40.0 & 6 & 60.0 & 3.30 & $0.63-17.45$ & 0.159 \\
\hline \multicolumn{8}{|l|}{ Age } \\
\hline$<40 \mathrm{y}$ & 10 & 43.5 & 13 & 56.5 & 1.00 & Reference & \\
\hline 40 y or over & 12 & 42.9 & 16 & 57.1 & 5.07 & $1.47-17.46$ & 0.042 \\
\hline \multicolumn{8}{|l|}{ Ingested during } \\
\hline Eating & 12 & 40.4 & 18 & 60.0 & 1.00 & Reference & \\
\hline Drinking & 4 & 36.4 & 7 & 63.6 & 1.30 & $0.32-5.24$ & 0.710 \\
\hline Sleeping & 4 & 57.1 & 3 & 42.9 & 0.22 & $0.05-1.85$ & 0.734 \\
\hline Coughing & 2 & 66.7 & 1 & 33.3 & 0.29 & $0.02-357$ & 0.790 \\
\hline \multicolumn{8}{|l|}{ Odinophagia } \\
\hline Yes & 22 & 43.1 & 29 & 56.9 & 1.00 & Reference & \\
\hline No & 0 & 0.0 & 0 & 0.0 & 0.29 & $0.09-0.95$ & 0.004 \\
\hline \multicolumn{8}{|l|}{ Dysphagia } \\
\hline Yes & 7 & 28.0 & 18 & 72.0 & 1.00 & Reference & \\
\hline No & 15 & 57.7 & 11 & 42.3 & 0.29 & $0.05-4.87$ & 0.522 \\
\hline \multicolumn{8}{|l|}{ Hypersalivation } \\
\hline Yes & 1 & 66.7 & 3 & 33.3 & 1.00 & Reference & \\
\hline No & 21 & 44.9 & 26 & 55.1 & 0.47 & $0.04-481$ & 0.627 \\
\hline \multicolumn{8}{|l|}{ X-ray } \\
\hline No Wire & 15 & 62.5 & 9 & 37.5 & 1.00 & Reference & \\
\hline Wire & 7 & 25.9 & 20 & 74.1 & 0.44 & $0.14-138$ & 0.009 \\
\hline \multicolumn{8}{|l|}{ Denture made by } \\
\hline Dentis & 16 & 47.0 & 18 & 52.9 & 35.0 & Reference & \\
\hline Dental technician & 6 & 35.3 & 11 & 64.7 & 1.00 & $0.96-10.83$ & 0.310 \\
\hline
\end{tabular}

Table 2. Some demographic medical characteristics of subjects after treating dental prosthesis

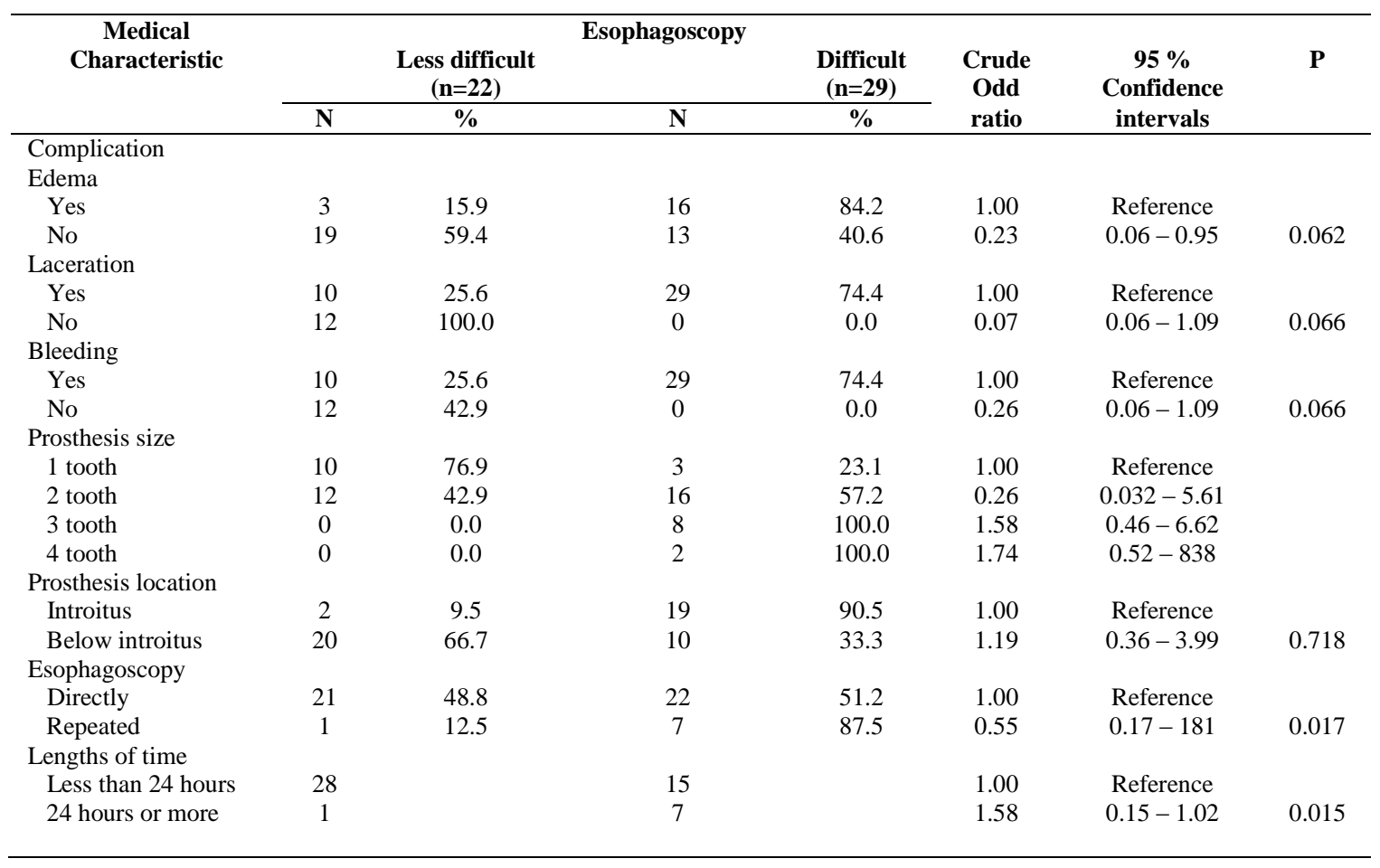




\section{DISCUSSION}

There were 34 dentures made by the dentis and 17 made by the dental technician. Statistically there was no correlation between who made the denture and difficulty in removing $(p=0.310)$. There were 21 dentures impacted at introitus esophagus and 30 dentures impacted below the introitus. Statistical analysis by chisquare tests there was no correlation between location impacted denture and difficulty in removing the denture $(\mathrm{p}=0.718)$. By T-test there were significant correlation between the amount of the tooth (1, 2, 3 and 4 teeth) and difficulty in removing $(\mathrm{p}=0.000), \mathrm{OR}=19.639$. Extraction of the denture with acrylic 4 teeth takes time for removing 19.639 times longer than removing denture with acrylic 1 tooth. Esophagoscopy for removing had been done in another hospitals previously, but they failed. Repeated esophagoscopy were performed on 8 patients. Statistically there was a significant correlation between repeated extraction caused by the failed of the first esophagoscopy and difficulty for removing the denture $(\mathrm{p}=0.017)$. Odd Ratio: 0.025 Edema, laceration of the mucosa and bleeding were the complications which occured after extraction the denture. In general, foreign body that has been ingested, pass through gastrointestinal system. If they impacted in the esophagus, esophagoscopy is usually required for removal. Ingested dental prosthesis in the esophagus must therefore be removed at the earliest opportunity. ${ }^{2,3,5}$ In this study 43 cases $(84.3 \%)$ came to the hospital less than 24 hours of ingestion and 8 cases $(15.7 \%)$ came to the hospital after 24 hours By T-test there is a significant correlation between the length of ingested time and the length of time for removing $(\mathrm{p}=0.015)$. Padmakumar et al. ${ }^{7}$ reported that sharp dentures and the size bigger than $7 \mathrm{~cm}$ are difficult to be removed esophagoscopically and have to be removed as early as possible by surgery. Barrows et $\mathrm{al}^{7}$ found that only $20 \%$ of psychiatric patients who ingested foreign body were seen in 24 hours of ingestion. In this study, the length of time required for removing a dental prosthesis by esophagoscopy was shorter while the patient came earlier to the endoscopic subdivision of Otorhinolaryngology. The risk of perforation during esophagoscopic removal of dental prosthesis is particularly high since of its rigidity, large size of acrylic with multiple sharp edges and has metal claps. Two cases had wire metal claps, could not be successful in removing and needed lateral cervicotomy.

\section{CONCLUSION}

To establish the diagnosis of an impacted dental prosthesis in the esophagus should have a careful clinical history, signs and symptoms, radiological examination and direct visualization through rigid esophagoscope. The chief complains are odynophagia and dysphagia. Statistical analysis revealed that, there was a significant correlation between wire and difficulties in management $(\mathrm{p}=0.009)$, there was a significant correlation between the length of time of ingested and difficulties in management $(\mathrm{p}=0.015)$, there was a significant correlation between failure of the first extraction and difficulties in management $(\mathrm{p}=0.017), 0 \mathrm{D}=0.025$, and there was a significant correlation between size the denture (amount of the tooth $1,2,3,4)$ and difficulties in management (p0.000), Odd Ratio :19.639 (4 to 1 tooth). Statistically there was no significant correlation between location impacted denture, denture made by a dentis or dental technician and difficulties in removing.

\section{Acknowledgment}

The author would like to thank to Dr. Bastaman Basuki from Department of Community Medicine, Faculty of Medicine University of Indonesia, Jakarta, Indonesia for correcting the statistics of this study.

\section{REFERENCES}

1. Moghissi K, Pender K. Instmmental perforation of the esophagus and their management. Thorax 1988; 43: 642-4.

2. Bloodworth KE, Render PJ. Dental acrylic resin radioopacity, literature review and survey of practitioners' attitude. JProsthet Dent 1992;67:121-3.

3. Stiles BM, Wilson WH, Bridges MA, Choudhuri A, Arias JR Nguyen BD et al. Denture esophageal impaction refractory to endoscopic removal in a psychiatric patient. $\mathbf{J}$ Emerg Med 2000; 18:323-6.

4. Stack LB, Munter DW. Foreign bodies in the gastrointestinal tract. Emerg Med Chin North Am 1996;14:493-521.

5. Webb WA. Management of foreign bodies of the upper gastro intestinal tract update. Gastrointest Endosc 1995; $41: 39-51$.

6. Abdullah BJJ, Teong LK, Mahadevan J, Jalaludin A. Dental Prosthesis Ingested and Impacted in the Esophagus and Orolaryngopharynx. J Otolaryngol 1998:27:190-4.

7. Padmakumar R, Balakrishnan, Alexander T, Vargheese S. Upper Gasto-intestinal Tract Foreign Body Denture Retrival by Gastrotomy. J Med Ass 2001 May http://www.iimaonline.org/may 2001/case notes $303 \mathrm{html}$ 